\title{
“We Stand for Black Livity!": Trodding the Path of Rastafari in Ghana
}

\author{
Shamara Wyllie Alhassan
}

School of Historical, Philosophical and Religious Studies at Arizona State University, Tempe, AZ 85281, USA; shamara.wyllie.alhassan@asu.edu

Received: 1 June 2020; Accepted: 8 July 2020; Published: 21 July 2020

\begin{abstract}
Rastafari is a Pan-African socio-spiritual movement and way of life that was created by indigent Black people in the grip of British colonialism in 1930s Jamaica. Although Rastafari is often studied as a Jamaican phenomenon, I center the ways the movement has articulated itself in the Ghanaian polity. Ghana has become the epicenter of the movement on the continent through its representatives' leadership in the Rastafari Continental Council. Based on fourteen years of ethnography with Rastafari in Ghana and with special emphasis on an interview with one Ghanaian Rastafari woman, this paper analyzes some of the reasons Ghanaians choose to "trod the path" of Rastafari and the long-term consequences of their choices. While some scholars use the term "conversion" to refer to the ways people become Rastafari, I choose to use "trodding the path" to center the ways Rastafari theorize their own understanding of becoming. In the context of this essay, trodding the path of Rastafari denotes the orientations and world-sensorial life ways that Rastafari provides for communal and self-making practices. I argue that Ghanaians trod the path of Rastafari to affirm their African identity and participate in Pan-African anti-colonial politics despite adverse social consequences.
\end{abstract}

Keywords: Rastafari; Ghana; Jamaica; Pan-African; trodding the path; livity

\section{Introduction}

I thought my parents were crazy for most of my life. I am a Black Rastafari woman and I grew up in a small, predominantly white, rural town on California's Lost Coast. I could not understand why my parents wore African clothes, their hair in dreadlocks or why they believed so vehemently in the positive valuation of Blackness ${ }^{1}$ in an anti-Black space. To understand my parents, I would need to overstand ${ }^{2}$ the spiritual communities they came from. For the past fourteen years, I have interviewed at least two hundred Rastafari in Jamaica, Ghana, and Ethiopia. The work that I present in this article is a small articulation of a broader project on the intersections of Rastafari, nation, gender, and Pan-African politics in Africa and the Caribbean. Here, my concern is to discuss the reasons people become Rastafari in Ghana and how this decision affects their social, political, and economic outlook. I use a portion of my interview with one Ghanaian woman to illustrate the ways Rastafari engages her in the broader struggle for social justice. I argue that Ghanaians trod the path of Rastafari

1 I have chosen to capitalize Black, Blackness, and Black African to empower these identities in my work and lowercase white to disempower white identity and white supremacy.

2 Overstand is a Rastafari word that transforms the English term "understanding" so that the sound of the word matches the meaning. Under-standing, sounds like one is under the message being communicated and Rastafari believes that if one is under something, the message cannot be properly received, but if one overstands something, then they are able to receive the message and extend the meaning with their own thoughts or opinions. 
to affirm their African identity and participate in Pan-African anti-colonial politics, despite adverse social consequences.

Rastafari is a Black Pan-African socio-spiritual movement, religion, and way of life ${ }^{1}$ that was created by Black working poor under British colonialism in 1930s Jamaica. Since at least the 1950s, Diasporan Rastafari have traveled to Ghana and other countries on the continent, and since the 1970s, Ghanaians began to trod the path of Rastafari. ${ }^{3}$ Informed by Ethiopianism, Pan-Africanism, Garveyism, Prophetism, and Back to Africa movements, Rastafari has burgeoned into a globalized way of life. ${ }^{4}$ Rastafari lifeways center Africa and decenter Europe as an epistemic frame of reference, propagate I-and-I consciousness (which is the notion that all human beings are connected through individual and collective divinity), and work toward the radical dismantling of all structures of "Babylon." ${ }^{5}$ Rastafari's fundamental contributions in the twenty-first century continue to center Africa, create a new Black beauty aesthetic, form anticolonial lived realities, offer a gender critique that advances the balance of male and female energies, ${ }^{6}$ and radically assert humanity for all Black people by making Emperor Haile Selassie I and Empress Mennen of Ethiopia divine. ${ }^{7}$

Exploring the ways travel and spirituality shape political solidarities amongst Diasporan and Ghanaian Rastafari enables theorizations about the ways people create anti-oppressive communities in the spirit of African Unity. The ability of Rastafari to build community across race, culture, language, gender, and nation has recently become a node of exploration for Rastafari Studies in continental Africa. ${ }^{8}$ Horace Campbell ${ }^{9}$ called for a shift away from simply studying the theology and symbols of the Rastafari movement in Jamaica or the Caribbean and instead argued for an explicit focus upon the ways Rastafari articulates itself in social, cultural, and political spheres. ${ }^{10}$ Monique Bedasse has called for scholars to engage with Rastafari travelers as central to the global reach of the movement and not just cultural iconography or reggae music. Continental Africa is a fruitful terrain for thinking about the social and political experiences of Rastafari. With the 2018 formation of the Rastafari Continental Council there is an urgency within the movement to enact and operationalize the Africa-centered cosmogony that galvanized the movement from the 1930s.

With special emphasis on the ethnography of one Ghanaian Rastafari woman, this paper analyzes some of the reasons Ghanaians choose to "trod the path" of Rastafari and the long-term consequences of their choices. While some scholars use the term "conversion" to refer to the ways people become Rastafari, ${ }^{11}$ I choose to use the notion of "trodding the path" to center the ways Rastafari theorize their own understanding of becoming. The concept of conversion is deeply embedded in the histories of Christian and Islamic domination in Africa and elsewhere. ${ }^{12}$ Even when the concept is not explicitly tied to these histories, it commonly denotes a Euro-centered and scripto-centric understanding of religion. While I appreciate the innovative notions of conversion that discuss the concept as a form of self-transformation, ${ }^{13}$ I do not think the conceptual category of conversion is adequate to account for

3 (Middleton 2006; White 2007, 2010; Bonacci 2015; Augier and Salter 2010).

(Edmonds 2012; Bonacci 2015).

5 "Global capitalism, which extracts resources from less developed countries, exploits the labor of the working class, and disproportionality enriches those individuals and countries that control capital, constitutes a contemporary manifestation of Babylon" (Edmonds 2012), pp. 39-40. Babylon can also denote policing, incarceration, the media, or any other tool used for the purpose of domination. Please see Horace Campbell, Rasta as Resistance, pp. 211-16.

6 This is true when we consider Rastafari women's thoughts specifically.

7 Emperor Haile Selassie was the last Emperor of Ethiopia, he was the first African leader to speak before the League of Nations in 1936.

8 Homiak (2013) argues that Carole Yawney theorized Rastafari as a "traveling culture," because of the movement's unique ability to maintain its heterogeneity and to translate to multiple spaces. The notion of traveling cultures borrows from James Clifford's theorizations.

9 (Campbell 1987, 1988).

10 Ibid.

11 (Chevannes 1994; Price 2009).

12 Please see (Olupona 2013).

13 Please see (Price 2009). 
the religious and spiritual experiences of Rastafari, because this is not the language they would use to overstand themselves. ${ }^{14}$

Most scholars of Africana religions use the terms initiation or homecoming to signal the ways Africana religious practices help them reveal more of their authentic selves and find spiritual community. Epistemic racism ${ }^{15}$ has denied scholars the ability to always foreground the language, categories, and theorizations of Black people. I explicitly choose to use the language, categories, and theorizations of Rastafari people to understand their spiritual and religious lives. Rastafari use the terms trodding the path, inborn concept, visions, and light to discuss the ways they became Rastafari. In the context of this essay, trodding the path of Rastafari is not a euphemism for conversion. Instead, it centers the epistemic categories and theorizations Rastafari use to understand themselves. Trodding the path denotes the orientations and world-sensorial ${ }^{16}$ life ways that Rastafari provides for communal and self-making practices.

\section{A Personal Perspective of Trodding the Path in Takoradi, Ghana}

Driving through the balmy Cape Coast heat to Takoradi in the Western Region of Ghana during the summer of 2017 was like a homecoming. We passed plantain trees and rich vegetation on the sides of the winding road. My husband, 6-month old son, and I were going to visit Sista Pama. Sista Pama was initially introduced to me as one of the only Rastafari women in Takoradi by a mutual friend. However, that was nine years ago, and I was excited to learn how things might have changed since I last saw her in person. We met at Montego Bay, her vegan restaurant and juice bar. She named it after the city in Jamaica where her mother lived for about sixteen years. The connections between Jamaica and Ghana have been long established through diplomatic and cultural relationships and the recent alleviation of visa requirements for both Jamaican and Ghanaian nationals. ${ }^{17}$ Rastafari has engendered these African and Caribbean cross-cultural connections through travel, music, and Pan-African politics. ${ }^{18}$

As we drove up to Montego Bay, we saw Sista Pama standing on the patio that served as an entrance to the restaurant. Her locks were longer than I remembered, and we alighted from the car and hugged her. Like most of the Rastafari women I interviewed, she took my son from me and sat down to play with him while we set her up with a microphone for our interview. Sista Pama is a strikingly beautiful golden-brown Ghanaian woman who was a TV personality when we first met in 2008. While she no longer had her TV talk show in 2017, her radio show and restaurant were going strong. When I asked her how she began to trod the path of Rastafari, she said, "Well, I actually started trodding the path of Rastafari at a radio station. I got this job and they told me they wanted to play reggae." ${ }^{19}$ She began to listen to the music lyrics and read more about the movement that produced the music. ${ }^{20}$ As she learned more about Rastafari, she was drawn to the positive Black African consciousness of the movement. She learned mostly on her own because there was not a big community in Takoradi. When she began to trod the path of Rastafari, her family was fine with her choice, but her community began to say things like, "'You are going mad.' 'You are now smoking weed.' 'Maybe you found yourself a Rasta boyfriend.'"21 She did not pay attention to those disparaging remarks because she was so focused on her own self-making journey. Other Ghanaian Rastafari women

\footnotetext{
14 During fourteen years of ethnography, I have yet to meet Rastafari that would describe the way they became Rastafari using the term 'conversion' or 'convert.' This is not to say they do not exist, but it is to say I have no empirical data to support the widespread use of the term.

15 Please see (Diakité and Hucks 2013, pp. 28-77).

16 (Oyěwùmí 1997).

7 Ghana, Jamaica Waive Entry Visa Requirements for Citizens BY: graphic.com.gh: https://www.graphic.com.gh/news/generalnews/ghana-news-ghana-jamaica-waive-entry-visa-requirements-for-citizens.html.

18 (Bedasse 2017)

19 Sista Pama, in discussion with the author (in Takoradi, Ghana), July 2017.

20 Most Ghanaians learn about Rastafari through reggae music. Please see (Middleton 2006; White 2007, 2010).

21 Sista Pama, in discussion with the author (in Takoradi, Ghana), July 2017.
} 
had similar experiences of discrimination. In an interview, Sista Agnes, discussed the way people thought she was insane and endangered her children because she locked their hair and raised them Rastafari. Mama Zion recounts the way people put their hands in her dreadlocks to see if her hair was real and assumed she was a foreigner even though she was born in Ghana. In fact, most Ghanaian Rastafari share that Diasporan Rastafari are more accepted than they are because it is assumed that Rastafari is a tradition for Diasporans and not Africans. One of the ways Ghanaian Rastafari are accepted in mainstream society is through the entertainment industry or if they go abroad and then come back to Ghana. These very narrow modes of social mobility prevent some people from growing dreadlocks or outwardly proclaiming their Rastafari identity. For example, Sista Agnes's husband decided not to grow dreadlocks so he could keep his job, but he still identifies as Rastafari.

One of the most important reasons people choose to become Rastafari is the movement's valuation of Black Africanness and its Pan-African anti-colonial politics. ${ }^{22}$ While there is a perception of Rastafari as foreign in terms of mainstream Ghanaian society, Ghanaian Rastafari think of the movement as African. African identity has been central to Rastafari belief systems, even in Jamaica. Most Jamaican Rastafari identify as African. Due to pervasive anti-Black racism and global white supremacy, the foundational Rastafari valuation of Black African identity and their continued fight for Black liberation and against all forms of oppression have galvanized aggrieved populations globally. Like Jamaica, Ghana was colonized by the British and this colonial process came with adverse psychological, cultural, religious, political, and economic impositions, which transformed the ways race, color, and indigenous African cultural practices were valued. ${ }^{23}$ Ghanaian political leaders and scholars like Osageyfo Dr. Kwame Nkrumah, ${ }^{24}$ Ayi Kwei Armah, ${ }^{25}$ Ama Ata Aidoo, ${ }^{26}$ and others have fought against neocolonialism and white supremacy and for the valuation of Black African knowledge systems. This Pan-African anti-colonial stance is amplified by the Rastafari movement because it captures the imagination of some segments of the Ghanaian population that desire a way of life that reflects their love of Black aesthetics, their fight for African unity, and their desire to affirm their precolonial African traditions and divinities. Although Rastafari has augmented Pan-African praxis in Ghana, the movement is stigmatized locally and internationally as mad or insane.

While the choice to become Rastafari leads to personal affirmation and access to an international community, it does not always translate into greater social and economic mobility in the broader societal context of Ghana due to stigma associated with the Rastafari movement. ${ }^{27}$ Historically, Rastafari purposefully embraced non-normative lifestyles and many took a militant or adversarial stance toward broader social structures upholding neo-colonialism and white supremacy, therefore Rastafari are prepared for adversity when they choose to trod the path. Ghanaian Rastafari overstand the risk associated with their choice to become Rastafari, but their commitment to joining an international community fighting for Black liberation and African unity outweighs the personal risk of losing friends, family, and economic viability. Sista Pama's ability to gain employment in radio and television was possibly due to more opportunities in the entertainment industry. Rastafari have often been able to gain employment as entertainers or in the tourist industry, but beyond these places of employment, many find significant obstacles. While much of the stigma associated with Rastafari has changed over time, brethren and sistren continue to experience challenges to social, political, and economic integration. Some of the Rastafari that I have worked with have been ostracized from their communities, plagued by chronic unemployment, forcibly committed to mental asylums, or unable to have a family because

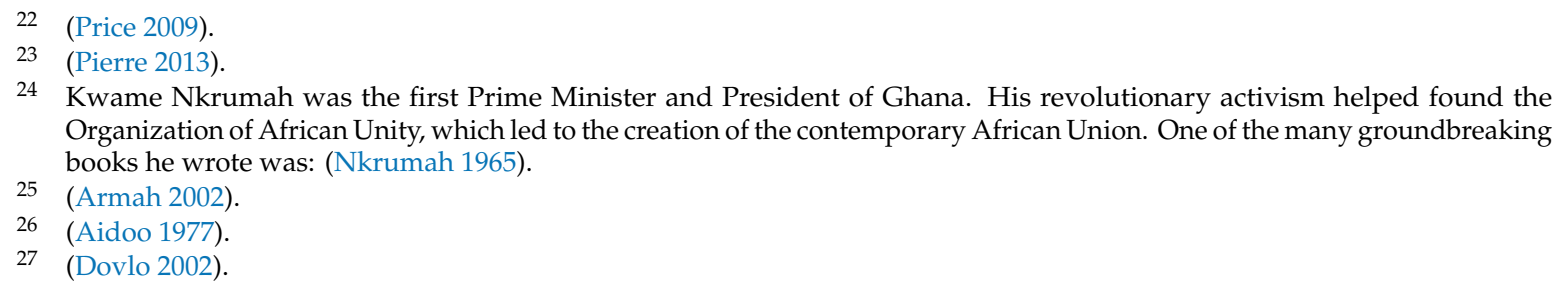

24 Kwame Nkrumah was the first Prime Minister and President of Ghana. His revolutionary activism helped found the Organization of African Unity, which led to the creation of the contemporary African Union. One of the many groundbreaking books he wrote was: (Nkrumah 1965). 
they are deemed undesirable partners. Despite adverse social consequences, becoming Rastafari is one avenue for Ghanaians to embrace decolonial Pan-African politics.

Sista Pama found positive affirmations of herself as an African woman through studying Garveyite philosophy and the Pan-African work of Emperor Haile Selassie and Empress Menen of Ethiopia. This positive valuation of Africanness allowed her to assert her decolonial practice with righteous conviction rooted in Black livity. Livity is a Rastafari concept that means lived philosophy. Livity guides the daily practice of decolonization that Rastafari undertake to free themselves from colonial and white supremacist anti-Black racism and center Pan-African liberation. When a person chooses to trod the path of Rastafari, she takes a non-normative path, particularly in environments where neocolonialism and white supremacist indebtedness to Eurocentrism are still the dominant purview. Sista Pama defies expectations by wearing African clothing and her natural hair and decentering Europe as a primary frame of reference. Although aware of the adverse social consequences, when we went to see Sista Pama, she spoke at length about how she has benefited from her choice to trod the path of Rastafari.

You know when you start to study the philosophies of Marcus Garvey and you learn about Emperor Haile Selassie and Empress Menen, you get a deeper understanding and a deeper knowledge of what you are doing. We are still learning, but now we are deep rooted and grounded and so we can stand firm and speak our minds freely. And tell them "A, this is it! We stand for truth and right! We stand for righteousness! We stand for Black livity! And we are very spiritual." 28

In this quote, Sista Pama reveals an important aspect of Rastafari livity: studying. Reading the philosophies of different Pan-African figures fortified and deepened her knowledge of Rastafari and allowed her to speak confidently about her Black spiritual politics. Her feeling of confidence allowed her to proudly proclaim, "we stand for Black livity," which became the title for this article. Ultimately, the more she read about African history and positive valuations of Blackness, the more empowered she became in who she was as a Black African woman. Therefore, Rastafari helps her to decolonize white supremacist anti-Blackness, reveal her authentic self, and be confident in her African consciousness. Despite social ostracism, the deep reading and knowledge seeking Rastafari engage in fortifies their embrace of Pan-African Rastafari philosophy and allows them to remain stalwart in their convictions. Charles Price ${ }^{29}$ has written extensively about the stigma people in Jamaica experience when they choose to become Rastafari and the ways this stigma helps affirm their choice rather than function as a deterrent. Ghanaian Rastafari are often discriminated against both in their homes and in their communities, because they eschew dominant interpretations of Christianity, which is the majority religious practice in Ghana. ${ }^{30}$ While there is a long way to go before there can be complete acceptance of Rastafari, the movement has become part of the fabric of Ghanaian history in terms of Rastafari activism in mainstream political, environmental, and social spheres in Ghana.

Ultimately, Sista Pama's choice to trod the path of Rastafari and endure the stigma associated with her choice is due to her commitment to the valuation of Africanness. Although the Rastafari movement began in Jamaica, she identifies it as an African way of life. She sees Africa as a Pan-African geography that is not only tied to land, but also tied to Black identity.

[Rastafari is] an African way of life. It will never be Jamaican because even in Jamaica, Jamaica is still Africa. Black people are living there. And wherever Black people are, it's Africa. You can be overseas, wherever you find yourself, but if your skin is black, you are an

28 Sista Pama (Rastafari woman in Takoradi, Ghana), in discussion with the author, July 2017.

29 (Price 2009).

30 While Christianity is introduced to Ghana through slavery and colonialism, there have been many movements such as the African Independent Church movement to indigenize Christianity. Thus, Rastafari is not the only mode through which people reclaim their African heritage. 
African. It's an African livity. You live it. It is not something that you can just do anyhow. It's an everyday thing like you wake up in the morning and you know you are supposed to brush your teeth. It's a livity, you live it, that's it.

For Sista Pama, being Black becomes central to overstanding her African identity. Nationality notwithstanding, Blackness shapes and articulates the decolonial politics that are expressed through livity. In addition to deep reading and seeking knowledge, the other important aspect of Rastafari livity is choosing to embrace a positive Black African identity every day. There are constant reminders of anti-Blackness that are pervasive in Ghana, whether it be the Spanish or East Indian TV soap operas that reinforce white beauty standards, bleaching creams that are sold openly in the market, or the social emphasis on learning more about Europe and the United States than other countries in continental Africa, these are just some of the few ways anti-Blackness can permeate a majority Black country. Choosing to embrace Blackness and read more about Black history allows Rastafari to consciously dismantle anti-Blackness. Sista Pama emphasizes that choosing to affirm Blackness must be conscious and happen daily. Her constant choice recognizes both the urgency and long-term political commitment that fighting for Black liberation and the valuation of Africanness entails. Her entrepreneurial endeavors align with her Rastafari consciousness. There are not many vegan restaurants in Ghana and many non-Rastafari Ghanaians view meat as an important staple of a meal. By opening Montego Bay, she introduces Takoradi to diverse food options which actively support the Rastafari notion of decolonizing the body through consuming healthy vegan plant-based food and drink. On her radio show, she plays reggae music and Ghanaian reggae artists in order to support local artists and the Pan-African lyrical content. In her personal life, she is mindful of the types of images of Africa her daughter consumes and actively teaches her daughter Black history and many of the Pan-Africanist figures in Africa and in the African Diaspora. Through her business, radio, and mothering, Sista Pama creates a space in Takoradi for the elevation of Black consciousness, Black liberation and Rastafari livity. When she first began to trod the path of Rastafari, people were weary of her because they did not understand what she was doing; now people gravitate towards her and actively want to know more about why she lives the ways she does. Ultimately, Rastafari has helped her become part of a broader international Black community that has fortified her even during the most difficult times.

While Sista Pama is not part of a particular mansion ${ }^{31}$ in Rastafari, her comments index the broader cultural and intellectual impacts Rastafari has had in Ghana through organizations like the Rastafari Council of Ghana, which is the umbrella organization that represents individual Rastafari mansions ${ }^{32}$ and organizations in the country. Ghana has become an epicenter of the movement on the continent through the creation of the Rastafari Council of Ghana, the launching of the Black Star Line Cooperative Credit Union in 2009,33 (which is one of the only Rastafari owned banking systems in the world), and the 2018 Rastafari Continental Council (RCC) election of Ghanaian Ahuma Bosco Ocansey (Daddy Bosco) as president. The RCC is the governing arm of the movement on the continent. Through national conferences, symposia, news articles, as well as other venues, these organizations advance their Pan-African agenda, which not only includes affirming African identity, but advocating for economic justice, environmental sustainability, and political enfranchisement. In 2014, the Rastafari Council of Ghana organized, alongside Food Sovereignty Ghana and other environmental groups, to place an embargo on the importation of GMOs; in 2015, they implored the Ghanaian government to

31 Mansions or houses are the Rastafari terms for organizations within the movement. These organizations differ ideologically and in practice. The three central organizations within Rastafari are the Nyahbingi, Twelve Tribes of Israel, and the Ethiopia-Africa Black International Congress.

32 Please see footnote 22 on why I use the term mansions.

33 The Black Starline Cooperative Credit Union was named after the Black Star Line, a shipping company that Marcus Garvey and the United Negro Improvement Association (UNIA), created in 1919 to transfer goods and repatriate people back to Africa and assist in attaining economic justice for Black people globally. Marcus Garvey's legacy and the notion of the Black star is also a prominent symbol of Pan-Africanism in Ghana with the Black star featured prominently in the Ghanaian flag and Kwame Nkrumah's admiration of Garvey. 
issue a solidarity statement in support of Palestinian sovereignty; in 2020 Rastafari spearheaded the movement to decriminalize cannabis, which won a small victory this year but remains a contentious issue. By engaging national discourses, the Rastafari Council positions itself as a major actor in the Ghanaian polity and extends itself beyond stigmatized particularity. The thwart refusal of Rastafari to be dismissed from the public sphere is part of their radical reclamation of space to advance their Pan-African agendas. The gains the Rastafari community in Ghana has made in recent years can only be understood in the larger frameworks of the Ghanaian polity, ideas of Pan-Africanism, and the heterogeneous cross-cultural development of Rastafari philosophy itself.

\section{Trodding the Path of Rastafari in Ghana's Religious Publics}

Although many scholars emphasize the Judeo-Christian basis for Rastafari philosophy, some have argued there is an over emphasis on Western notions of Christianity and not enough research concerning the ways traditional African spiritualities provide core foundations for Rastafari. ${ }^{34}$ Everything from the notion of a Black God, ${ }^{35}$ marijuana as holy sacrament, and dreadlocks to reggae music, Pan-Africanism, and aspects of the Hebrew bible have roots in African cultural, spiritual, and political practices. ${ }^{36}$ Maureen Warner-Lewis ${ }^{37}$ details the continuities between Akan traditional spirituality in Ghana and Rastafari. In her essay, "African Continuities in the Rastafari Belief System," Warner-Lewis writes that a belief in human beings as divine is fairly common throughout West African societies and that Kings and Queens normally represent this divinity. Thus, Emperor Haile Selassie's divinity can be rationalized not only through biblical lineage, but also through West African cosmologies. The Rastafari notion of the self as a spirit being that lives eternally, is also a common notion in West Africa. ${ }^{38}$ The self in the spiritual dimension of life is underscored by the Rastafari concept of eternal life. Rastafari practitioners proclaim, "Rasta cannot die." ${ }^{39}$ Beyond a purely biological conception of being human, there is an eternal living state of being that exists in the spiritual dimension. This concept of the human as spiritual and connected to a universal metaphysical force that incorporates the ancestors and all living things is a basic conception in Rastafari. ${ }^{40}$

Finding connections between Rastafari and African continuities of thought in the Caribbean is significant because Rastafari not only imagines Africa and views Africa as coeval politically, but spiritually retains world-senses that are direct continuities of sacred African knowledge systems. However, as Elom Dovlo ${ }^{41}$ points out, African traditional religion is constantly changing and sometimes when Rastafari seek “... spiritual and cultural roots in African Traditional Religions, often, they discover that the traditional spirituality they seek, though available, is not always openly accepted by westernized and Christianized Africans they come into contact with." ${ }^{\prime 2}$ The tension between Ghanaian religiosity and societal stigma is disconcerting to Diasporan Rastafari who journey to Ghana and Ghanaian Rastafari who begin to trod the path in search of ancestral and spiritual renewal. In

34 (Savishinsky 1998, pp. 140-41).

35 It is important to note that the concept of a Black God comes from a variety of Africana Religions and is not just a province of Rastafari or continental Africa. Notably, the African American Christian Religious tradition from Albert Cleage Jr. to James Cone has cast God as Black and Christ as Black. This notion of Black divinity ultimately supports the notion that Black people are human beings.

36 Savishinsky uses compelling anthropological data from a variety of African ethnic groups, mostly from central Africa, as evidence for his arguments.

37 (Warner-Lewis 1993, pp. 108-23).

38 Divinity is therefore conceptualized as self-created and self-perpetuated, outside of Man, but on another level. It is also conceptualized as incorporating culture-heroes together with the accumulated spirit-force of human ancestors ... Given the innate godliness of Man-Man cannot die ... Life is thus conceived not only as a biological state. It has a spiritual dimension as well. Hence the paradoxical belief that spirit being the full realization of human potential and is a more powerful state than temporal existence (Warner-Lewis 1993, pp. 112-13).

39 (Chevannes 1994).

40 (Owens 1976; Salter 2008).

41 (Dovlo 2002).

42 Ibid 
fact, the stigmatization of African traditional religious practices and Rastafari is similarly articulated due to the comparable aesthetic appearances of Rastafari and African Traditional priests. ${ }^{43}$ Darren Middleton writes, "It seems highly likely that some of these early Rastas noted the similarity between the appearance of Rasta celebrities like Bob Marley, with his long matted hair, and traditional African fetish priests and, therefore, perceived Rastafarianism as an authentically African way of life ... More than a few non-Rastafarian Ghanaians remarked to me that with the emergence of Rastafarianism among Ghanaian youth in the mid-to-late 1970s, fetish priests found a wider audience for their words and deeds." ${ }^{44}$ The renowned fetish priest, Okomfo Anokye, who many say brought the golden stool from the sky that has become the life force of the Asantehene, ${ }^{45}$ has a statue in Kumasi that depicts his cowrie shell studded dreadlocks. The relationship between Rastafari and African traditional spirituality creates new spaces for sharing and exchange in the spiritual publics of Ghana, but it has also meant shared stereotypes and stigma.

Ghana remains a predominantly Christian country, with a strong Muslim community and a smaller community that practices African indigenous religion. Some Muslims in Ghana also practice Rastafari and call themselves Rasmuslims. While Rasmuslims are not necessarily changing the practice of Islam, they use the Quran to rationalize Rastafari beliefs and aesthetics. Rastafari evolves through a Black circuit of ideas and thus the heterogeneity of spiritual beliefs and practices comprising Rastafari in West Africa are constantly changing according to the needs, contexts, and histories of the people. ${ }^{46}$ Africana religions are utilitarian in that people draw from the spiritual and religious traditions and healing methods that they need in order to achieve their goals. Within Rastafari, the fight for Black liberation is central to overstanding its overall spiritual cosmogony and appeals to Ghanaians who achieved the political kingdom in 1957 through independence from Britain but are still fighting to decolonize religiously, psychologically, and economically. Through livity, or daily acts of decolonization of food, language, dress, and reasonings or extended spiritual conversations around race, politics, and building a new egalitarian world, Rastafari opens up epistemic and spiritual spaces for diverse groups to build anti-oppressive societies and fight for Black liberation. ${ }^{47}$

Dovlo $^{48}$ argues that neo-religious, political, and cultural movements come to Ghana seeking a route home, and this route is augmented by Sankofa movements that seek to spiritually and politically return Africans to the source of their own human dignity. He writes, "Ghanaians can identify with the call to return to culture. This has been part of the cultural policy of governments since independence. It is currently espoused and popularized in the concept of 'Sankofa.' Apart from its artistic manifestation such as in clothes, theatre, music etc., there is a deep longing for the traditional sense of community as pertained in the past." 49 Movements like Rastafari inspire some Ghanaians on their own anti-colonial journeys. However, while many youth or people already outside social norms may join these movements, they are still subject to increased social precarity.

\section{The Rastafari Trod Is a Constant Choice: Considerations for Future Scholarship}

We left Sista Pama's Montego Bay vegan restaurant and juice bar enriched and thankful for the time she shared with us. The landscape in Ghana has transformed in the nine years that I have known her. She remarked that now many Ghanaian women and girls admire her dreadlocks and want to learn more about Rastafari. When I first met her in 2008, dreadlocks were still definitively connected to African traditional priests and were heavily stigmatized. While in Ghana in 2017, I noticed an

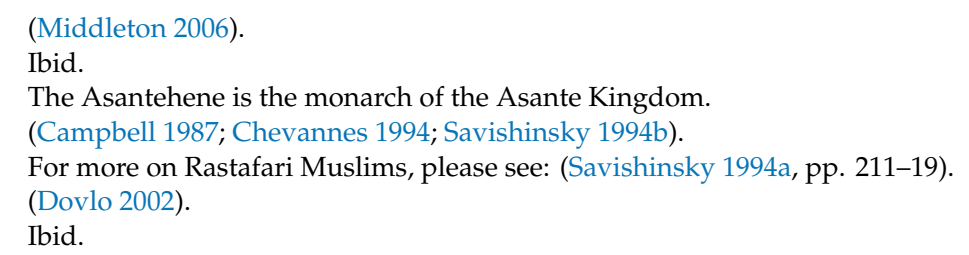


increase in hair salons catering to natural Black hair and natural hair expos where dreadlocks were a featured hairstyle. The former First Lady of Ghana, Lordina Mahama and the current Minister of Communication and Technology, Hon. Ursula Owusu-Ekuful wear their hair in dreadlocks and employers, beyond the entertainment industry, have begun to accept employees with the hairstyle. Many of the people wearing dreadlocks are not necessarily Rastafari, but their embrace of the hairstyle represents the broad-based cultural influence of both African traditional spirituality and Rastafari. These promising transformations signal that the movement's development over time will be important to watch in terms of the ways Rastafari is able to influence the religious and Pan-African publics of Ghana.

The choice to trod the path of Rastafari is complex both for the individual and for the community as a whole. By centering the language of trodding the path, this article centered the categories that Rastafari people have used to think about their lives and their practices. Epistemic racism still shapes the reasons some scholars continue to employ Eurocentric conceptual categories and frameworks to overstand the experiences of Africana people. Through individual narratives, such as Sista Pama's, or the work of the Rastafari organizations, the movement on the continent is producing important and innovative ways of thinking about contemporary Pan-African consciousness. Considering Rastafari in Ghana opens a space for questioning the way religion is understood in West Africa, the disciplinary divisions between Africa and the African Diaspora, and the way nation, imperialism, and neo-colonialism still work to construct impediments in the lives of brethren and sistren. The personal self-making practices engendered by Rastafari, provide new avenues for considering how people employ Rastafari as a framework for asserting human dignity and advancing the cause for African Unity. These self-making and community building practices fashion new realities for people choosing to trod the path of Rastafari in the Ghanaian polity.

Funding: This research received no external funding.

Conflicts of Interest: The authors declare no conflict of interest.

\section{References}

Aidoo, Ama Ata. 1977. Our Sister Killjoy or Reflections from a Black-eyed Squint. London: Longman.

Armah, Ayi Kwei. 2002. KMT In the House of Life. Popenguine: Per Ankh Pub.

Augier, Roy, and Veronica Salter. 2010. Rastafari: The Reports. Kingston: Caribbean Quarterly, Cultural Studies Initiative, UWI.

Bedasse, Monique A. 2017. Jah Kingdom: Rastafarians, Tanzania and Pan-Africanism in the Age of Decolonization. Chapel Hill: The University of North Carolina Press.

Bonacci, Giulia. 2015. Exodus! Heirs and Pioneers, Rastafari Return to Ethiopia. Kingston: The University of the West Indies Press.

Campbell, Horace. 1987. Rasta as Resistance: From Marcus Garvey to Walter Rodney. Trenton: Africa World Press.

Campbell, Horace. 1988. Rastafari as Pan-Africanism in the Caribbean. African Journal of Political Economy 2: 75-88.

Chevannes, Barry. 1994. Rastafari Roots and Ideology. Syracuse, New York: Syracuse University Press.

Diakité, Dianne M. Stewart, and Tracey E. Hucks. 2013. Africana Religious Studies: Toward a Transdisciplinary Agenda in an Emerging Field. Journal of Africana Religions 1: 28-77. [CrossRef]

Dovlo, Elom. 2002. Rastafari, African Hebrews \& Black Muslims: Return 'Home' Movements in Ghana. In Exchange 31. No. 1. The Netherlands: Brill.

Edmonds, Ennis. 2012. Rastafari: A Very Short Introduction. Oxford, England: Oxford University Press.

Middleton, Darren J. N. 2006. As It Is In Zion: Seeking The Rastafari in Ghana, West Africa. London: Equinox Publishing Ltd.

Homiak, John. 2013. When Goldilocks Met the Dreadlocks: Reflections on the Contributions of Carole D. Yawney to Rastafari Studies. In Let Us Start With Africa: Foundations of Rastafari Scholarship. Edited by Jahlani Niaah and Erin MacLeod. Jamaica: The University of the West Indies Press, Institute of Caribbean Studies, pp. 56-116.

Nkrumah, Kwame. 1965. Neocolonialism: The Last Stage of Imperialism. London: Thomas Nelsons \& Sons. 
Olupona, Jacob. 2013. African Religions: A Very Short Introduction. Oxford, England: Oxford University Press. Owens, Joseph. 1976. Dread: The Rastafarians. London: Heinemann.

Oyěwùmí, Oyèrónké. 1997. The Invention of Women: Making An African Sense of Western Gender Discourses. Minneapolis: University of Minnesota Press.

Pierre, Jemima. 2013. The Predicament of Blackness: Postcolonial Ghana and the Politics of Race. Chicago: The University of Chicago Press.

Price, Charles. 2009. Becoming Rasta: Origins of Rastafari Identity in Jamaica. New York and London: New York University Press.

Salter, Richard. 2008. Rastafari in a Global Context: Affinities of 'Orthognosy' and 'Oneness' in the Expanding World. In IDEAZ: The Globalization of Rastafari. Edited by Ian Boxill. Kingston: Arawak Publications, vol. 7, pp. $10-27$.

Savishinsky, Neil J. 1994a. Baye Faal of Senegambia: Muslim Rastas in the Promised Land? Africa: Journal of the International African Institute 64: 211-19. [CrossRef]

Savishinsky, Neil J. 1994b. Rastafari in the Promised Land: The Spread of a Jamaican Movement among the Youth of West Africa. African Studies Review 37: 19-50. [CrossRef]

Savishinsky, Neil J. 1998. African Dimensions of the Jamaican Rastafarian Movement. In Chanting Down Babylon: The Rastafari Reader. Philadelphia: Temple University Press.

Warner-Lewis, Maureen. 1993. African Continuities in the Rastafari Belief System. Caribbean Quarterly 39: 108-23. [CrossRef]

White, Carmen M. 2007. Living in Zion: Rastafarian Repatriates in Ghana, West Africa. Journal of Black Studies 37: 677-709. [CrossRef]

White, Carmen M. 2010. Rastafarian Repatriates and the Negotiation of Place in Ghana. University of Pittsburgh of the Commonwealth System of Higher Education. Ethnology 49: 303-20.

(C) 2020 by the author. Licensee MDPI, Basel, Switzerland. This article is an open access article distributed under the terms and conditions of the Creative Commons Attribution (CC BY) license (http://creativecommons.org/licenses/by/4.0/). 